\title{
Biodegradation of phenol by alkaliphiic Bacillus badius D1
}

\author{
V. D. Sarwade ${ }^{1}$, K.R. Gawai ${ }^{2}$ \\ ${ }^{1,2}$ University of Pune, Department of Chemistry, Ganesh Khind, Pune, 411007.(MS)India.
}

\begin{abstract}
Phenols have been recognized as mutagenic and carcinogenic. Industrial effluents possessing phenols causes' environmental pollution. Present study was planned to investigate the \% degradation of phenol using alkaliphilic Bacillus badius D1 with various concentration ranging from 0.42 to $1.68 \mathrm{~g} / \mathrm{L}$ in alkaline broth of $\mathrm{pH}-9$, in shaking incubator at $110 \mathrm{rpm}, 37^{\circ} \mathrm{C}$. The \% degradation at lowest concentration was about 98\%. Even at higher concentration the rate of degradation was found higher than $70 \%$. The \% degradation and spectroscopic profile was monitored from 0 to $48 \mathrm{hr}$. by $6 \mathrm{hr}$. interval. The metabolic pathway was constructed by isolating and characterizing the metabolites by ${ }^{1} H N M R$, FTIR, and GCMS. It was concluded that the Bacillus badius follows ortho and meta catechol pathway for degradation. The biodegradation study was extended for varying parameters like temperature, $\mathrm{pH}$, salinity, additional carbon and nitrogen sources.
\end{abstract}

Key words: Biodegradation, phenol, Bacillus badius

\section{Introduction:}

Phenol is one of the most widely used organic compounds and is a basic structural unit for a variety of synthetic organic compounds including agricultural chemicals and pesticides. Phenol is naturally found in decaying dead organic matters like rotting vegetables as complex polymer lignin or humic acids [1] and in coal [2]. At room temperature phenol is a translucent, colorless, crystalline mass, white powder or syrupy liquid. The crystals are hygroscopic and turn pink to red in air. Phenol has a sweet tar like odor and is soluble in alcohol, glycerol, petroleum and water to a lesser extent [3].

Petroleum refineries pulp and paper manufacturing plants, resins and coke manufacturing, wood preservation plants, pharmaceutical industries generate huge amounts of waste water that usually contain higher concentrations of different contaminants beyond acceptable discharge levels. The main contaminants of these industries include phenols [4], polycyclic aromatic hydrocarbons as well as heavy metals [5]. Among these toxic pollutants, phenols are considered to be the most hazardous chemicals, and they are certainly the most difficult to remove. Phenol may be fatal by ingestion, inhalation, or skin absorption, since it quickly penetrates the skin and may cause severe irritation to the eyes and the respiratory tract. It is listed among the priority organic pollutants by the US Environmental Protection agency [6] as a toxic chemical. It is considered to be potentially carcinogenic to humans and may be lethal to fish at concentrations of $5-25 \mathrm{mg} / \mathrm{L} \mathrm{[7].} 0.1 \mu \mathrm{g} / \mathrm{mL}$ and higher concentration of phenol cause the inhibition of photosynthesis of diatoms and blue green algae [8]. Phenol is inhibitory to the nitrification process [9] at and above $1000 \mathrm{mg} / \mathrm{L}$. The $\mathrm{NO}_{2}$ groups on phenol are inhibitory to methanogenesis. Phenols and catechols reveal peroxidative capacity, they are hematotoxic and hepatotoxic. It provokes mutagenesis and carcinogenesis in humans as well as other living organisms [10]. Accumulation of phenol creates toxicity to flora and fauna [11]. Since phenol is toxic and causes pollution, it must be removed from the environment. As physicochemical methods are harsh and expensive; hence microbial degradation and bioremediation seems a good alternative for conventional physico-chemical methods.

Biodegradation of materials involve initial proximity, allowing adsorption or physical access to the substrate, secretion of extra cellular enzymes to degrade the substrates or uptake via transport systems followed by intracellular metabolism. The metabolism and efficiency of biodegradation of organic compounds is influenced by nature of pollutant, the nature of the organism, the enzymes involved in degradation and the nature of the influencing physicochemical factors like moisture content, $\mathrm{pH}$, temperature [12], etc. Several lines of investigations have shown the degradation of phenols by neutrophilic bacteria [13-22] and fungi [23-28]. The degradation reports of phenol by alkaliphiles are very less [29-35]. In this studies attempt has been made to examine the degradative potential of alkaliphilic starin Bacillus badius D1 obtained from pristine Crater Lake Lonar MS. India

\section{Material and method:}

2.1 Chemicals: Phenol, 4 aminoantipyrine and solvents were purchased from SRL Mumbai. Bacteriological media chemicals from Himedia, Mumbai and chemicals for enzymes from sigma and SRL,

2.2. Biodegradation study: Nine $500 \mathrm{ml}$ conical flasks with $250 \mathrm{ml}$ alkaline broth media were used for biodegradation study. $1 \%$ inoculum of $24 \mathrm{hr}$. grown culture was added and allowed to grow for $24 \mathrm{hr}$ in shaking incubator at $37 \mathrm{0C}, 110 \mathrm{rpm}$. At the end of $24 \mathrm{hr} 1.4 \mathrm{~g} / \mathrm{L}$ phenol was added in each flask. The pattern of phenol 
degradation was monitored by UV-vis spectra at each interval of $6 \mathrm{hr}$. Un utilized amount of phenol from each flask was estimated spectroscopically by the method of Gorden et al[36] at $510 \mathrm{~nm}$ after 15 min by plotting standard graph.

Remaining supernatant was further used for the extraction of metabolites of phenol generated during biotransformation. The residue was obtained by Rota evaporator and further purified by preparative TLC or column chromatography. The structural determination of the metabolite were carried out by spectroscopic analysis like FTIR, ${ }^{1} \mathrm{HNMR}$ and GCMS.

\subsection{Effect of various parameters on phenol degradation:}

Effect of parameters like various phenol concentration, $\mathrm{pH}$, temperature, salinity, and additional carbon and nitrogen sources also studied similarly.

\subsection{Preparation of cell free extract and enzyme activities:}

Isolation of cell mass, cell free extract was carried by Du Pont Soverall cold centrifuge at 10,000 x g, protein content was determined by Lawry method. CYP - 450 content was estimated by Omura and Sato [37, 38]. The enzyme activities of microbial biotransformation enzymes after induction by phenol were carried. SOD was evaluated by Mishra and Fridovich [39]. Acetanilide hydroxylase was analyzed by Shenkman [40] Wiserberg and Goodal [41]. The cat 1, $2 \mathrm{O}$ was determined by Urszula Guzik [42]; while the cat 2, 3O by Grekova $[43,44]$.

III. Result and Discussion:

3. 1 Degradation of phenol by alkaliphilic strain Bacillus badius D1:

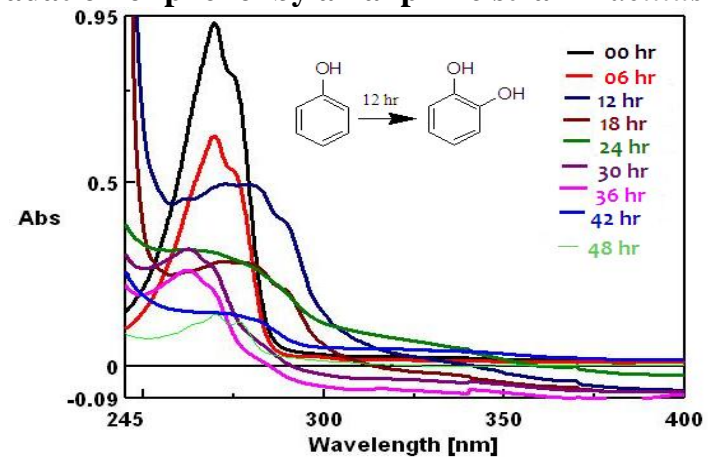

Fig. 1 UV vis-spectra of phenol degradation

"Fig". 1 indicates the degradation pattern of phenol by Bacillus badius D1. Phenol at concentration of $1.5 \mathrm{~g} / \mathrm{L}$ of growth medium was incubated with bacterial strain at $370 \mathrm{c}$ for $48 \mathrm{hr}$. The degradation pattern was monitored at every $6 \mathrm{hr}$ interval on UV-visible spectrophotometer. After $6 \mathrm{hr}$ incubation, decrease in the height of peak at $270 \mathrm{~nm}$ was observed. Further incubation up to $12 \mathrm{hr}$ the peak at $270 \mathrm{~nm}$ was found to be disappeared. At the end of $48 \mathrm{hr}$ complete degradation of phenol was observed.

\section{2 Effect of various parameters on degradation of phenol:}

\subsubsection{Effect of various concentration of phenol on degradation:}

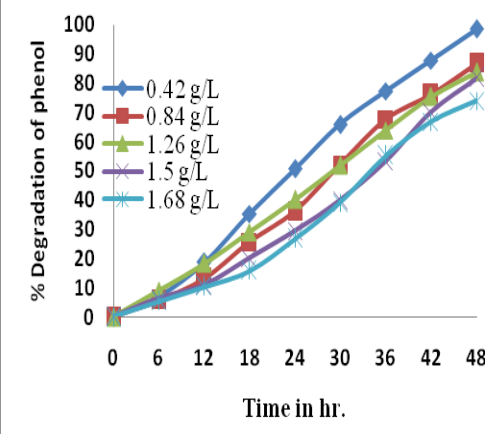

Fig. 2. Effect of various concentration of phenol on \% degradation

"Fig".2 indicates the effect of various concentrations of phenol on degradation by Bacillus badius D1. To evaluate the degradation potential of this strain,the bacterial strain was incubated with various concentrations 
of phenol in growth media ranging from $0.42 \mathrm{~g} / \mathrm{L}-1.68 \mathrm{~g} / \mathrm{L}$ for $48 \mathrm{hr}$. $98.47 \%$ degradation of phenol was observed at the end of $48 \mathrm{hr}$ at $0.42 \mathrm{~g} / \mathrm{L}$ concentration. Gradual decrease in the phenol degradation was observed with increase in the concentration. Even at higher concentration $1.68 \mathrm{~g} / \mathrm{L}$ the degradation rate was found to be more than $70 \%$.

\subsubsection{Effect of $\mathrm{pH}$ on phenol degradation:}

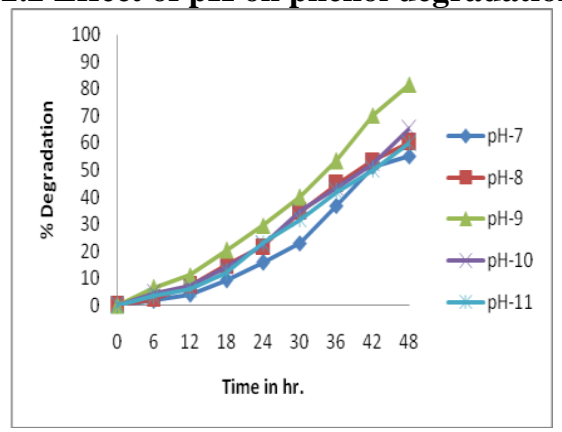

Fig. 3 Effect of $\mathrm{pH}$ on phenol degradation

"Fig". 3 Showes the effect of $\mathrm{pH}$ on degradation of phenol by alkaliphilic Bacillus badius D1. In order to examine the phenol degradation potential of this strain, the strain was incubated with phenol at a concentration of $1.5 \mathrm{~g} / \mathrm{L}$ at $370 \mathrm{C}$ in shaking incubator for $48 \mathrm{hr}$. with various $\mathrm{pH}$ values ranging from 7.0- 11.0. Data obtained has indicated that at $\mathrm{pH} 9.0$ maximum 82 percent of phenol degradation was observed within 48

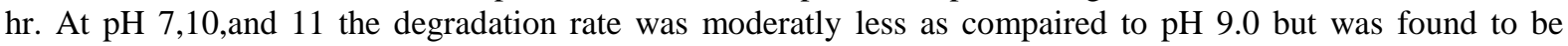
significant.This data suggest that this bacterial strain shows high degradative activity in alkaline media.

\subsubsection{Effect of Salinity on biodegradation of phenol:}

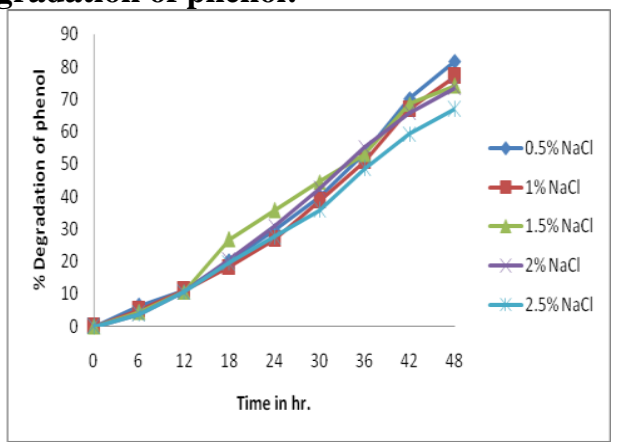

Fig. 4 Effect of salinity on biodegradation of phenol

The effect of various concentration of $\mathrm{NaCl}$ on the degradation of phenol by this bacteria has been shown in "Fig".4. To elucidate the effect of salinity on the degradation of phenol, the bacterial strain was incubated with phenol at a concentration of $1.5 \mathrm{~g} / \mathrm{L}$ in growth media at $37{ }^{0} \mathrm{C}$ in shaking incubator for $48 \mathrm{hr}$. with various concentrations of sodium chloride ranging from $0.5 \%-2.5 \%$. The result obtained from this study indicates that $82 \%$ degradation of phenol was observed at $0.5 \%$ of $\mathrm{NaCl}$ concentration. With further increase in the salinity up to $2.5 \% \mathrm{NaCl}$ has resulted in slight decrease in the rate of phenol degradation.

\subsubsection{Effect of temperature on phenol degradtion:}

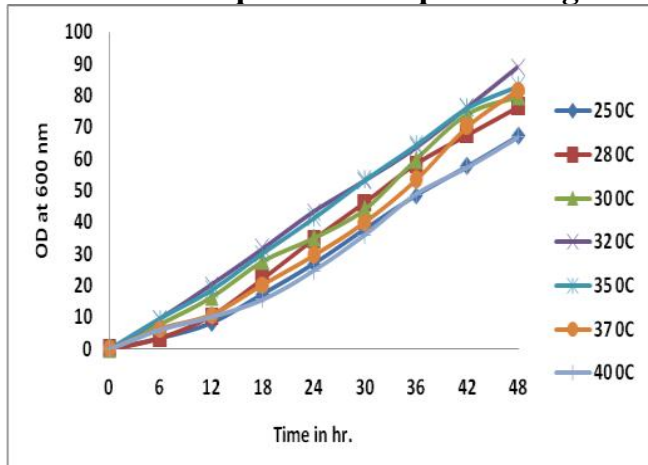

Fig.5 Effect of temperature of phenol degradtion 
In order to examine the effect of temperature on phenol degradation by Bacillus badius D1.The bacterial strain was incubated with phenol at aconcentration of $1.5 \mathrm{~g} / \mathrm{L}$ at $370 \mathrm{C}$ in shaking incubator for $48 \mathrm{hr}$. with various temperatures ranging from $250 \mathrm{C}$ to $40{ }^{\circ} \mathrm{C}$. Results obtained indicates that "Fig." 5 the maximum degradation rate was found between $30{ }^{\circ} \mathrm{C}-35{ }^{\circ} \mathrm{C}$. With lower and higher temperature the degradation rate was found to be marginally decreased.

\subsubsection{Effect of different carbon sources on phenol degradation:}

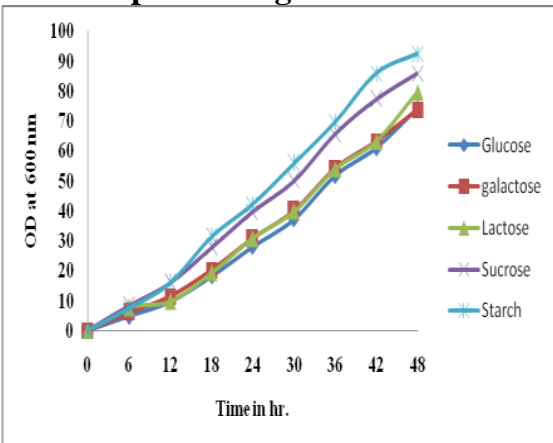

Fig 6 Effect of different carbon sources on phenol degradation

"Fig". 6 indicates the effect of various carbon sources on phenol degradation. In presence of $0.5 \%$ sugars as additional carbon sources like glucose, galactose,lactose,sucrose, and starch respectively. Marginal increase in percent degradation was observed in all carbon sources however, starch was found to be better carbon source for the degradation as comparitive to other carbon sources used.

\subsubsection{Effect of various nitrogen sources on phenol degradation:}

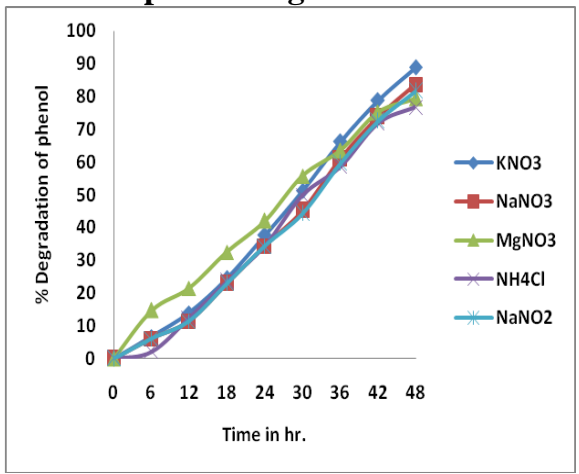

Fig.7. Effect of various nitrogen sources on phenol degradation

"Fig".7. shows the effect of various mineral nitrogen sources. In order to examine the effect of various nitrogen sources like $\mathrm{KNO}_{3}, \mathrm{NaNO}_{3}, \mathrm{MgNO}_{3}, \mathrm{NH}_{4} \mathrm{Cl}$ on phenol degradation by Bacillus badius D1.The bacterial strain was incubated with phenol at a concentration of $1.5 \mathrm{~g} / \mathrm{L}$ at $37{ }^{0} \mathrm{C} \mathrm{pH} \mathrm{9.0,110} \mathrm{rpm} \mathrm{gyration} \mathrm{in} \mathrm{shaking}$ incubator for $48 \mathrm{hr}$. On providing the nitrogen soures at $0.02 \mathrm{~g} / \mathrm{L}$. it is reveled that the maximum degradation rate was found in $\mathrm{KNO}_{3}$ as compaired to other nitrogen sources.

\subsubsection{Effect of phenol on various biotransformation enzymes:}

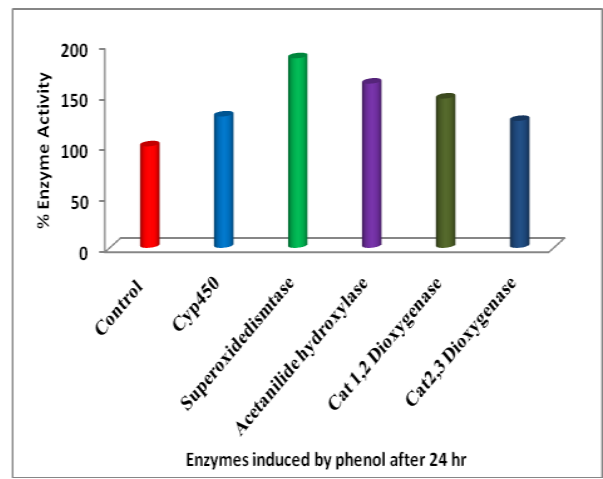

Fig.8. Effect of phenol on various biotransformation enzymes 
"Fig".8 showed the effect of phenol on the activities of microbial biotransformation enzymes like super oxide dismutase, Acetanilide hydroxylase, catechol 1,2 dioxygenase, catechol 2,3 dioxygenase and the content of cytochrome P-450 To evaluate the effect of phenol on these biotransformation enzymes, bacterial strain Bacillus badius D1 was incubated with phenol at a concentration of $1.5 \mathrm{~g} / \mathrm{L}$, for $24 \mathrm{hr}$. at $37{ }^{0} \mathrm{C}$, in growth media $\mathrm{pH}$ 9.0. Incubation with phenol for $24 \mathrm{hr}$. was resulted significant increase in the content of cytosolic cytochrome P-450 ( $30 \%$, ) and in the activities of acetanilide hydroxylase $(62 \%)$ super oxide dismutase $(86 \%)$, Catechol 1,2 dioxygenase (47\%) and catechol 2,3 dioxygenase (25\%) as compaired to their respective controls. However, the magnitude of increase in the content of cytochrome P450 and the activities of superoxide dismutase, catechol 1,2 dioxygenase were found to be higher than acetanilide hydroxylase and catechol 2,3 dioxygenase.

\subsubsection{Spectroscopic analysis of intermediate metabolites during phenol degradation by Bacillus badius D1:}

Phenol was found to be transformed into catechol by the bacterial strain Bacillus badius DI at the end of $12 \mathrm{hr}$. incubation. The conformation was done by HNMR data $\delta-5.33(\mathrm{~S}-2 \mathrm{H}), \delta-6.8(\mathrm{~m}-4 \mathrm{H})$,FTIR stretches at Ar-OH-3229, Ar-1517-159 and mass spectrographic data showing molecular ion peak at110 and its fragmentation observed at 92,80,64,53,40. Catechol was further converted in to cis -cis muconic acid at the end of $30 \mathrm{hr}$. The metabolite structure was confirmed by H NMR delta values $\delta-12.9(\mathrm{~S}-2 \mathrm{H}), \delta-6.21(2-\mathrm{H}), \delta$ 7.59(2H), the FTIR stretches observed at Ar-COOH - b-3043-2575,Ar-1635-1674, while mass spectrographic data indicated the molecular ion peak at 142 and the fragmentation pattern appeared at $142,123,114,96,83,71,56,43,38$.

\subsubsection{Tentative Phenol biodegradation pathway by Bacillus badius:}

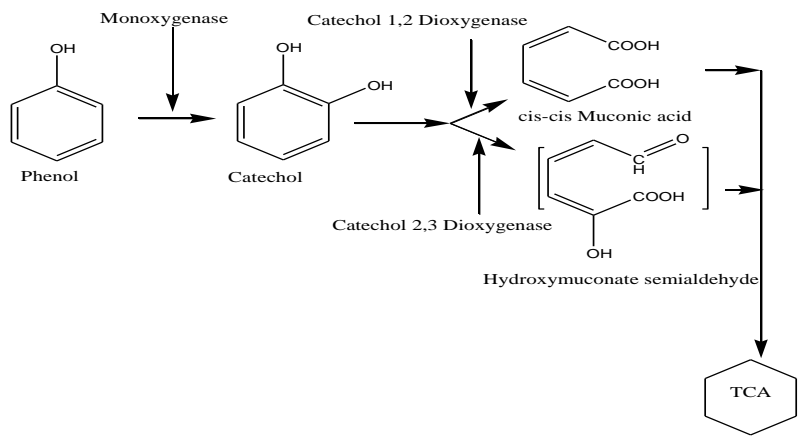

Fig (9) Tentative Phenol biodegradation pathway by Bacillus badiusD1

"Fig". 9 indicates the proposed degradation of phenol by Bacillus badius D1 (No - HQ. 015711. 1) Incubation phenol $1.5 \mathrm{~g} / \mathrm{L}$ with this bacteria resulted in formation of different metabolites. The initial reaction catalized by microbial monoxigenase resulted in formation of catechol.In the next step ring fission was occurred due to dioxygenase forming cis - cis muconic acid and hydroxyl muconic semialdehyde. The formation of these intermediates could be attributed to catechol 1,2 dioxygenase and catechol 2,3 dioxygenase. Finally the aliphatic moieties has been completely oxidized via TCA cycle.

\section{Discussion:}

Several chemical compounds having diverse chemical structure like aromatic, aliphatic, phenolic, polycyclic aromatic hydrocarbons, nitro aromatics have been known to have adverse effect on environment as well as human being. Phenol is naturally found in decaying dead organic matters like rotting vegetables as complex polymer lignin or humic acids and in coal [45]. These aromatic hydrocarbons have been known to induce or inhibit the mixed function oxidase system in animals [46, 47] birds [48]. Various hydrocarbons are major constituents of coal, crude oil and naturally occurring. Biodegradation of these compounds have been reported by other investigators [49-53]. Microorganisms have a broad range of biochemical pathways in order to utilize these organic compounds [54-57]. Aerobic incubation of phenol with alkaliphilic strain Bacillus badius D1 at a concentration of $1.5 \mathrm{~g} / \mathrm{L}$ resulted in $85 \%$ degradation within $48 \mathrm{hr}$. showing the promising degradation potential of this strain. In other studies, using Pseudomonas fluorescence KNU417, [phenol 1,300 mg/L] degradation was reported within $65 \mathrm{hr}$ [58]. The lower degradation rate was observed due to increased toxicity at higher concentration. It is reported [59] that bidegradation rate decreased at higher concentration of increased toxicity of metabolites. Degradation rate was found to be different with respective experimental parameters. In case of $\mathrm{pH}$ when phenol was incubated with Bacillus badius D1maximum degradation rate was found at $\mathrm{pH}$ 9.0.This observation indicate that alkaliphilic strain can efficiently degrade phenol at higher $\mathrm{pH}$ [60]. 
Temperature affect the microbial enzyme activities and thus rate in metabolic pathway. The highest degradation of phenol was observed in the range between 30 to 35 0C.The decreases in rate of degradation at higher temperature could be attributed to the temperature effect on enzyme molecule. Salinity also one of the experimental factor play important role in degradation [61]. The highest degradation rate of phenol was observed at $0.5 \% \mathrm{NaCl}$. Increase in the salinity has resulted in moderate decrease in degradation rate. Additional carbon sources like glucose, galactose, lactose, sucrose and starch resulted in significant increase in the rate of degradation $[62,63]$ of phenol however, in case of starch maximum rate of degradation was found. Indicating that utilization of starch by bacteria could give the sufficient amount of reducing equivalents for the biotransformation of phenol supply. Addition of inorganic nitrogen sources has shown significant rate of increase in degradation. Indicating that these sources provides the required nitrogen for the growth of bacteria.

The involvement of microbial enzymes like cytochrome P450, superoxide dismutase, Acetanilide hydroxylase, catechol 1,2 dioxygenase, catechol 2,3 dioxygenase in xenobiotic biotransformation is well established. Incubation of phenol with alkaliphilic bacterial strain has resulted in increase in the activity of these enzymes and the content of cytochrome P-450.This increase may be due to inductive effect of either a parent molecule or its metabolites on the gene responsible for coding these enzymes. Similar type of result of aromatic compound metabolism by microorganisms has shown the induction of these enzymes $[64,65]$.

Variety of microorganisms including bacteria and fungi are capable to degrade wide variety of organic compounds. Some bacteria have ability to degrade these compounds both aerobically and anaerobically [66, 67]. Bacterial degradation of aromatic compounds is often initiated by addition of hydroxyl group in the structure their by producing hydroxyl moiety [68]. This has been reported by many investigators [69-71]. In the next step this hydroxyl moiety is attacked by dioxygenase [72-74]. Incubation of phenol with alkaline strain Bacillus badius has resulted stepwiswe biotransformation of phenol via catechol [75], muconate [76], and suspected muconate semialdehyde [77] to TCA cycle. Our findings suggest that this alkaliphilic strain has a great potential to degrade phenol in extreme conditions.

\section{Conclusion:}

The strain Bacillus badius D1 was found highly efficient in degradation of phenol. It can be used for commercial and industrial bioremediation of phenol at polluted sites. As it showed cis-cis muconic acid in the broth media indicates involvement of induction of o -catechol fission pathway. The induction of catechol 2, 3 dioxygenase enzyme confirms that it also follow m-fission pathway of catechol. Although, various enzymes like CYP- 450, acetanilide hydroxylase, superoxide dismutase, catechol 1,2 dioxygenase, catechol 2,3 dioxygenase were found induced, among these the magnitude of superoxide dismutase induction is higher.

Authers are thankful to UGC, India.

\section{Acknowledgements:}

\section{References:}

[1]. Fredric Ampe, David Leonard, Nicholsas, D. Lindley. Repression of Phenol Catabolism by Organic Acids in Ralstonia eutropha, Applied and Environmental Microbiology, 64:1-6, 1998

[2]. Manojlovica D, Ostojic D.R, Obradovic B.M, Kuraica M.M, Krsmanovica V.D, Puric J. Removal of phenol and chlorophenols from water by new ozone generator, Desalination 2007; 213: 116-122.

[3]. Khazi M. B, Aravindan Rajendran, Viruthagiri Thangavelu., Recent advances in the Biodegradation of Phenol: A review, Asian j. Exp. Biol. Sci., 2010; 1: 219-234.

[4]. Farooqi I H, Basheer F, Ahmad T. Studies on biodegradation of phenols and m-cresols by upflow anaerobic sludge blanket and aerobic sequential batch reactor, Global NEST Journal, 2008;10: 39-46.

[5]. Muftah H. E-Naas., Shaheen A. Al-Muhtaseb, Souzan Makhlouf. Biodegradation of phenol by Pseudomonas putida immobilized in polyvinyl alcohol (PVA) gel, Journal of Hazardous Materials 2009; 164: 720-725

[6]. Keith L.H, Telliand W. A. Priority pollutants, Environ. Sci.Technology.1979;13: 416 -423.

[7]. Kumar A, Kumar S. Biodegradation kinetics of phenol and catechol using Pseudomonas putida MTCC 1194, Biochem. Eng. Journal 2005; 22: 151-159.

[8]. Shail Singh, Beer Bahadoor Singh, Ram Chandra. Biodegradation phenol in batch culture by pure and mixed strains of Panibacillus and Bacillus cerus, Polish journal of microbiology 2009; $58: 319-325$.

[9]. Amor L., Eiroa M., Kennes C., Veiga M.C. Phenol biodegradation and its effect on the nitrification process, Water Research 2005; 39: 2915-2920.

[10]. Michałowicz J., Duda W. Phenols - Sources and Toxicity university of Lodz, Faculty of biology and environment Protection, 2006; $12: 347-361$.

[11]. Indu Nair, Jayachandran K, Shankar Shashidhar. Biodegradation of phenol, African Journal of Biotechnology 2008; 7: 4951-4958.

[12]. Junshi Miyamoto, Environmental and health issues. Pure and App. Chem.1996; 68: 1737-1748.

[13]. Adav S. S., Lee D.J. Aerobic granulation of pure bacterial strain Bacillus thuringenesis, Front. Environ. Sci. Engin. China 2008; 2: 461-467.

[14]. Geng Anil, Alwyn E. W. S. Isolation and characterization of a phenol-degrading bacterium from an industrial activated sludge, Appl. Microbiol Biotechnol. 2006 ; 71:728-735.

[15]. George P. P., Andrew J. D. Enhanced biodegradation of phenol by a microbial consortium in a solid-liquid two phase partitioning bioreactor, Biodegradation, 2005; 16: 329-339. 
[16]. Viggor Signe, Heinaru Eeva, Kunnapas Allan, Heinaru Ain, Evaluation of different phenol hydroxylase possessing phenoldegrading pseudomonads by kinetic parameters, Biodegradation. $2008 ; 19$ : 759-769.

[17]. Prasanna N, Saravanan N, Geetha P, Shanmugaprakash M, Rajasekaran P . Biodegradation of Phenol and Toluene by Bacillus sp, Pseudomonas sp. and Staphylococcus sp., Isolated from Pharmaceutical Industrial Effluent, Advanced Biotech. 2008 ; 20: 1-5.

[18]. Agarry S. E, Solomon B. O. Kinetics of batch microbial degradation of phenols by indigenous Pseudomonas fluorescence, Int. J. Environ. Sci. Tech., 2008; 5: 223-232.

[19]. Jame1 S. A., Rashidul Alam A.K.M., Fakhruddin Khorshed Alam Md. Degradation of Phenol by Mixed Culture of Locally Isolated Pseudomonas Species, Journal of Bioremediation Biodegradation. 2010; pp 1-4.

[20]. Koc Nur, Kilic B, Pinar K. Biodegradation of phenol by Synechocystis sp. in media including triacontanol hormone, Water and Environment Journal, 2011; pp-1-6.

[21]. Marı Teresa, Garcia., Gallego, Virginia., Ventosa, Antonio., Encarnacion Mellado, Thalassobacillus devorans gen. nov., sp. nova moderately halophilic, phenol-degrading, Gram-positive bacterium, International Journal of Systematic and Evolutionary Microbiology 2005;55: 1789-1795.

[22]. P. Saravanan, K. Pakshirajan, Prabirkumar Sah. Biodegradation of phenol and $\mathrm{m}$-cresol in a batch and fed batch operated internal loop airlift bioreactor by indigenous mixed microbialculture predominantly Pseudomonas sp. Bioresource Technology 2008;99: 8553-8558.

[23]. Guoying Wang, Jianping Wen., Guanghai Y, Hongmei Li, Anaerobic biodegradation of phenol by Candida albicans PDY-07 in the presence of 4-chlorophenol, World J. Microbiol. Biotechnol. 2008;24 : 2685-2691.

[24]. Lidianne, L. R. R, Aguiar C. R, Martins Cavalcante., Isolation and characterization of phenol-degrading yeasts from an oil refinery wastewater in Brazil, Mycopathologia 2007 ; 164:183-188.

[25]. Uddysoriyan C., PrabuP.C. Biodegradation of phenol by ligninolytic fungus Tramets versicolor,Journl of Biological Sciences. 2005;5: 824-827.

[26]. Jiang, Yan., Nanqi, Ren, Biodegradation of Phenol and 4-Chlorophenol by the Mutant Strain CTM, Chinese Journal of Chemical Engineering, 2008; 16: 796-800.

[27]. Stoilova, Ivanka., Krastanov, Albert., Bui, H., , Biodegradation of mixed phenolic compounds by microbial association of Aspergillus awamori and Thermoascus aurantiacus,Electronic Journal of Environmental Agricultural and Food Chemistry, 2008;7: PP-2625-2633.

[28]. Liming Wang, Yanwen Lin., Linyan Y.P.Y.,Zhixiong Xie, Luo Y., 2011. Candida tropicalis: characterization of a strain capable of degrading high concentrations of phenol, Biotechnol Lett. DOI 10.1007/s10529-011-0534-7,

[29]. Maltseva O., Oriel P. Monitoring of an Alkaline 2,4, 6-Trichlorophenol-Degrading Enrichment Culture by DNA Fingerprinting Methods and Isolation of the Responsible Organism, Haloalkaliphilic Nocardioides sp. Strain M6, Appl. Environ. Microbiol. 199 7; $63: 4145-4149$

[30]. Yuanyuan Qu., Ruijie Zhang., Fang Majiti, Zhou Bin Yan. Bioaugmentation with a novel alkali-tolerant Pseudomonas strain for alkaline phenol wastewater treatment in sequencing batchreactor, World J Microbiol Biotechnol. 2011; DOI 10.1007/s11274-0110653-2

[31]. Kanekar P.P., Sarnaik S. S., Kelkar A.S. Bioremediation of phenol by alkaliphilic bacteria isolated from alkaline lake of Lonar, IndiaJournal of Applied Microbiology Symposium Supplement, 1999; 85: 128-133.

[32]. Celso S.I. O., Albaugh Catherine, Pyton Brent., Benzoate and salicylate degradation by Halomonas campisalis an alkaliphilic moderately halophilic microorganism, Water Research, 2007; 41: 1232-1242.

[33]. Peyton Brent., Alva V., C. Oie, Mormile, M.R., Biotransformation of Toxic Organic contaminants by halophilic bacteria from Soap Lake,WA., Research \& Extension Regional Water Quality Conference 2002 (1-3)

[34]. Sylvie Le Borgne., Dayanira Paniagua., Rafael V.D., Biodegradation of Organic Pollutants by Halophilic Bacteria and Archaea, J Mol Microbiol Biotechnol 2008; 15,74-92.

[35]. Ravikumar S.,Gokulakrishnan R., Parimala, P.S., Biodegradation of phenol and cyanide compounds by using halobacteria, International Journal of Current Research, 2011; 3: 096-100.

[36]. Gorden, G. E., Colorimetric Determination of Phenolic Materials in Refinery Waste Waters, 1960; 32: 1325-1326.

[37]. Omura T., Sato T.R. The Carbon monoxide-binding Pigment of Liver Microsomes, J. Of Biol.Chem. 1964 ; 239: 2370-2378.

[38]. Suk-Jung, Choi Kim Mira.,Kim, Sung-I, Jeon Joong-Kyun. Microplate Assay Measurement of cytochrome P450-Carbon Monoxide Complexes, Journal of Biochemistry and Molecular Biology, 2003; 36: 332-335.

[39]. MisraH.P, Fridivich. I., The Role of Superoxide anion in the autoxidation of epinephrine and a simple assay for superoxide dismutase J.Biol Chem. 1972;247:3170-3175

[40]. Shenkman J. B., Remmer, H., Estabrook, R.W., Spectral studies of drug interaction with hepatic microsomal cytochrome. Mol. Pharmacol, 1967; 3:113-23.

[41]. Weisburger and Goodal, Steric inhibition of enzyme reactions: Lack of enzymic hydrolysis of 2, 4, 6 trimethylacetanilide, Life Sciences. 1968; pp-263-268

[42]. Guzik Urszula., Gren Izabela., Wojcieszyska Danuta, Abuek, Sylwia., Isolation and characterization of a novel strain of Stenotrophomonas maltophila possessing various dioxygenases for monocyclic aromatic hydrocarbon degradation, Brazilian Journal of Microbiology 2009; 40:285-291.

[43]. Grekova-Vasileva, M. Topalova Y., Enzyme activities and shifts in microbial populations associated with activated sludge treatment of textile effluents, Biotechem. and Biotechnol. 2009; 23: 1136-1142.

[44]. Sala -Trapet J.M, Evans C.W., The meta Cleavage of Catechol by Azotobacter Species 4-Oxalocrotonate Pathway, Eur. J. Biochem. 1971 ; 20: 400-413.

[45]. Manojlovica D., Ostojic D.R., Obradovic B.M., Kuraica M.M., Krsmanovica V.D., Puric J., Removal of phenol and chlorophenols from water by new ozone generator, Desalination 2007; 213: 116-122.

[46]. Yamazaki Hiroiki S, Urano T, Inoue K , Shimida T. Effects of roxithromycin, erythromycin and troleandomycin on their Ndemethylation by rat and human cytochrome P450 enzymes. Xenobiotica, 1996; 26: 1143.

[47]. S. S. Chauhana, P. K. Srivastavaa, V. K. Srivastavaa, V. Kumara, U. K. Misrab. Inhibition of coal fly ash polycyclic aromatic hydrocarbons and metals induced mixed-function oxidase activity in rat lung and liver by vitamin A and citrate, Journal of Toxicology and Environmental Health. 1986; 17: 357-363

[48]. Arleen B. Rifkinda, Shigeru Sassaa, Jennifer Reyesa, Haidrun Muschicka. Polychlorinated aromatic hydrocarbon lethality, mixedfunction oxidase induction, and uroporphyrinogen decarboxylase inhibition in the chick embryo: dissociation of dose-response relationships. Toxicol Appl Pharmacol. 1985;78: 268-79.

[49]. H. Al-Awadhi, Rasha H. D., Sulaiman Huda, Mahmoud M., Radwan S. S., Alkaliphilic and halophilic hydrocarbon-utilizing bacteria from Kuwaiti coasts of the Arabian Gulf, Appl Microbiol Biotechnol. 2007; 77:183-186. 
[50]. Robert A. Kanaly, Shigeaki Harayama. Biodegradation of High-Molecular-Weight Polycyclic Aromatic Hydrocarbons by Bacteria Bacteriol. 2000;182: 2059-2067.

[51]. Chauhan Archana, Fazlurrahman Oakeshott, John G, Jain Rakesh K., Bacterial metabolism of polycyclic aromatic hydrocarbons:strategies for bioremediation, Indian J. Microbiol., 2008; 48: 95-13

[52]. Margesin R., Schinner F. Biodegradation and bioremediation of hydrocarbons in extreme environments, Appl Microbiol Biotechnol 2001;56: pp 650-663.

[53]. Pizzul Leticia, Castillo Maria del Pilar, Stenstrom John. Characterization of selected actinomycetes degrading polyaromatic hydrocarbons in liquid culture and spiked soil, World Journal of Microbiology and Biotechnology. 2006; 22: pp 745-752

[54]. Clarke P.H., Gibson, D. T., , Microbial degradation of organic compounds. Marcell Dekker, New York publishers, 1984; ISBN: 08247-7102-8.

[55]. Vander, Meer. J.R, Devos, W. M., Harayama, S., Zehnder, A., 1992, Molecular mechanisms of genetic adaptation to xenobiotic compounds, Microbiol Rev, 56, pp 677.

[56]. Van Der Meer, J.R. Evolution of novel metabolic pathways for the degradation of chloroaromatic compounds. Antonie Leeuwenhoek, 1997; 71: 159- 178.

[57]. Williams P. A., Sayers J.R., 1994, The evolution of pathways for aromatic hydrocarbon oxidation in Pseudomonas Biodegradation 5, pp 195-217.

[58]. Kyung H. K., Sung H. Y., Optimal microbial adaptation routes for the rapid degradation of high concentration of phenol, Bioprocess Biosyst. Eng. 2009;32: 435- 442.

[59]. Chang B.V., Shiung L.C., Yuan S.Y., Anaerobic biodegradation of polycyclic aromatic hydrocarbon in soil. Chemosphere 2002;41: 1463-1468.

[60]. Krishnaswamy V. G., Namasivayam V. Effect of pH, Nitrogen sources and salts on degradation of phenol by bacterial consortium under saline conditions, International journal of Biotechnology and biochemistry,. 2010; 6:783-791. ISSN 0973-2691

[61]. Chunyu Y., Zhe Wang., Yang Li., Yu Niu., Miaofen Du. Metabolic versatility of halotolerant and alkaliphilic strains of Halomonas isolated from alkaline black liquor, Bioresource Technology 2010; 101: 6778-6784.

[62]. Chakraborty S., Bhattacharya T., Patel T.N., Tiwari K.K.,.,Biodegradation of phenol by native microorganisms isolated from coke processing waste water, Journal of Environmental Biology, 2010; 31: 293-296.

[63]. ] Kotresha D.,Vidyasagar G. M. Isolation and characterisation of phenol-degrading Pseudomonas aeruginosa MTCC 4996, World J Microbiol Biotechnol. 2008; $24: 541-547$.

[64]. Bragg , J. R., Prince, R.C., Harner E. J., Atlas, R.M., 1994, Effectiveness of bioremediation for the Exxozon Valdez oil spill, Nature ,368,413-418.

[65]. Vinosa A.D., Suidan, M.T., Wrenn, B.A., Strohmear K.L., Haines J.R., Eberhart B.L., King D., Holder E. Environmental Science and Technology. 1996;30:1764 -1775.

[66]. Haiyin Xu, Thomas M., Chen S., Cirneglia C.E., Cen H., , Anaerobic Metabolism of 1-Amino-2-Naphthol-Based Azo Dyes (Sudan Dyes) by Human Intestinal Microflora, Applied Environmental microbiology, 2007; 73: 7759-7762.

[67]. Lewine, W.G. Metabolism of azo dyes: implication for detoxication andactivation. Drug metabolite Rev. 1991; 23: 253-309.

[68]. Stiborova M., Sucha, V., Mikanova M. J., Paca J. Hydroxylation of Phenol to Catechol by Candida tropicalis: Involvement of Cytochrome P450, Gen. Physiol. Biophys. 2003; 22: 167-179.

[69]. Piakong Mohd. Tuah., Noor Aini., Abdul Rashid., Madihah Md. Salleh., Degradation pathway of phenol through cleavage by Candida tropicalis, Boreno Science. 2009; 24:1-8.

[70]. BaggiG., AndreoiniV., Co-metabolic degradation of mixtures of mono chloro phenols by phenol-degrading microorganisms, Annals of Microbiology, 2002; 52: 133-143.

[71]. Finkel'shtein Z. I, Baskunov, B. P., Golovlev, E. L. Dependence of the Conversion of Chlorophenols by Rhodococci on the Number and Position of Chlorine Atoms in the Aromatic Ring, Microbiology, 2000; 69: 40.

[72]. Bernard J. Finklet, Ring Cleavage of plant catechols by crystalline oxygenases, Phytochemistry. 1971;10: 235 to 242.

[73]. Sung Cheolkoh, Michael V.M, Dennis D. Focht. Biodegradation of 2, 4-Dichlorophenol through a Distal meta-Fission Pathway, Applied and Environmental Microbiology. 1997;,pp. 2054-2057.

[74]. Angelika,S., Klaus, F., Friedriich, Lottspeich. Degradation of 2-methylaniline in Rhodococcus rhodochrous: cloning and expression of two clustered catecho1 2,3 dioxygenase genes from strain CTM, Journal of General Microbiology, 1991; 137: 20412048.

[75]. Chandrakant Karigar, Aravind Mahesh, Phenol degradation by immobilized cells of Arthrobacter citreus, Biodegradation. 2006; 17: 47-55.

[76]. Victor A. A, Brent M. Peyton. Phenol and Catechol Biodegradation by the Haloalkaliphile Halomonas campisalis: Influence of $\mathrm{pH}$ and Salinity, Environ. Sci. Technol. 2003; 37: 4397 - 4402.

[77]. Wael S. Sayyed, Mohamad K. Ibrahim. Isolation and characterization of phenol catebolizing bacteria from coke plant, Bioscience, Biotech, Biochem, 2003;67: 2026-2029. 